\title{
Cytotoxic Effects of Indian Tobacco Rolls (Bidi) Smoke Extract on Macrophages \& its Prevention by Alkaloid Vasicine Obtained by Adhatoda vasica
}

\author{
Mamta Pant, Sujata Basu, Rachana * \\ Department of Biotechnology, Jaypee Institute of Information Technology, A-10, Sector-62, Noida-201307, Uttar Pradesh, India
}

\begin{abstract}
Address for Correspondance

Rachana, rachana.dr@iitbo mbay.org
\end{abstract}

\section{Keywords}

Vasicine;

Adhatoda vasica;

Cytotoxicity.

\section{INTRODU}

\section{CTION}

Tobacco smoking is a major cause of respiratory ailments in urban and rural India. It contains thousands of chemical constituents which lead to an increase in oxidative stress resulting into cell death and inflammatory conditions. Tobacco smoke (TS) contains an extremely high number of harmful products of various chemical nature, in both gas and tar phases. Majorly, they are in the form of free radicals (ROS \& RNS) which range from $10^{14}-10^{15} /$ puff [1]. One of the causes for unwanted health effects due to tobacco 4(3): 135 .

\begin{abstract}
Bidi, a form of hand-rolled cigarette, is prevalent mostly in rural India. On its combustion during smoking, tobacco wrapped inside a bidi, accounts for generation of tremendous amount of harmful free radicals and carcinogenic chemicals. These chemicals are known to increase oxidative stress in an exposed biological system, causing cell death. The present study is an attempt to investigate the protective effect of antioxidant and anti-inflammatory compound, Vasicine (active compound of Adhatoda vasica) against the toxic effects induced by bidi smoke concentrate (BSC) on human macrophages (THP-1 cell line). The effect of BSC, Vasicine, and their combinations was analyzed on cell viability on THP-1 cells through MTT assay. Results have shown that Vasicine pre-treatment protected the cells against BSC-induced oxidative stress. Further, cells exposed to above treatments were analyzed under inverted microscope and it was observed that, BSC caused tremendous decrease in cell density and change in size, thus affecting the cell viability and morphology of the cells. Vasicine pre-treatment retained the cell viability of the cells exposed to bidi smoke concentrate (BSC) to $11 \pm 0.03 \%$ in comparison to control. On estimating Nitric oxide (NO) radical scavenging activity it was observed that, BSC treatment significantly increased the nitrite level in cells. This level remained unchanged in Vasicine pre-treated cells. BSC treatment increased SOD activity also, and Vasicine pre-treatment kept this activity almost near to control. Thus, it can be suggested from this study that strong antioxidant potential of Vasicine might have protected THP-1 cells. Further investigation is required to unveil its deeper molecular mechanism of action. (C) 2015 iGlobal Research and Publishing Foundation. All rights reserved.
\end{abstract}

NOTE: Full length manuscript of Pant et al. Cytotoxic Effect of Indian Tobacco Rolls (Bidi) Smoke Extract on Macrophages and its Prevention by Alkaloid Vasicine Obtained From Adhatoda Vasica. 2014; 


\section{Indo Global Journal of Pharmaceutical Sciences, 2015; 5(2): 99-105}

exposure of these toxic substances due to high vascularity of the lung tissue [7]. Normally, immune cells fight back to cope up with the stress induced by the tobacco smoke and in this process they may succeed or else may also add up to the inflammatory phenomena, which ultimately can lead to diseased conditions [8].

Any biological system exposed to this kind of stress tries to neutralize the toxic effects through enzymatic and nonenzymatic antioxidant defence mechanisms [9]. This includes scavenger enzymes like Superoxide dismutase (SOD), Catalase (CAT), Glutathione peroxidase (GPx) and Glutathione reductase (GR); Vitamins like; $\mathrm{C}$ and $\mathrm{E}$ and, non-protein thiols, etc [10].

To aid these internal antioxidant mechanisms, external supplements can also be used to balance the oxidative state of a system. Since ancient time, medicinal herbs are being used to treat many diseases and disorders without knowing their mechanism of action. Most of them have various degree of antioxidant activity and might also have specific targets, as well. One of such, widely used herbs is, Adhatoda vasica. It has been used to treat various respiratory and other inflammatory ailments [11]. Despite of its tremendous use, this plant has not been explored much to analyse its mechanism of action for such treatments.

Few known active ingredients of Adhatoda vasica are Vasicine, Vasicinone, 2'-Hydroxy-4Glucosyloxychalcone, Vasicol, Vasicinol and Deoxyvasicinone etc [12]. Vasicine is one of the major active constituent of this herb which has been reported to be responsible for majority of its biological activities. It is known to act as an antioxidant and anti-inflammatory agent [13].

Present study is an attempt to investigate the toxic effect of Indian tobacco rolls concentrate on human macrophages (THP-1 cell line) and to analyze if, Vasicine could prevent the tobacco smoke induced toxicity along with its mechanism of action.

\section{MATERIALS \& METHODS}

\section{Chemicals and Reagents}

Ethanol, glycerol, were brought from CDH Ltd., New Delhi, India. Fetal bovine serum (FBS), RPMI-1640 and trypsin-EDTA were acquired from Himedia, Bombay,
India. 4-(2-hydroxyethyl)-1-piperazineethanesulfonic acid (HEPES), sodium nitroprusside, ethylene diamine tetra acetic Acid (EDTA), Triton-X 100, 12-Otetradecanoylphorbol-13-acetate (TPA), protease inhibitor cocktail, 3-(4,5-dimethyl-thiazol-2-yl)-2,5-diphenyl tetrazolium bromide (MTT), nitroblue tetrazolium bromide (NBT), and pyrogallol were purchased from Sigma-Aldrich, USA.

\section{Cell culture}

THP-1 cells (human monocytes cell line) were obtained from National Centre for Cell Science (NCCS), Pune, India and were cultured and maintained by standard methods [14].

\section{Preparation of Bidi Smoke Concentrate (BSC)}

The tobacco rolls (bidi) were purchased from the local market, and were used to prepare BSC by passing the vapour phase of bidi smoke obtained from complete combustion of three bidis, into $3 \mathrm{ml}$ of incomplete medium, in a compact set-up. The concentrate (considered as $100 \%$ BSC) was made fresh for every set of experiment [15].

\section{Treatment of THP-1 cells with TPA}

For initiating any experiment with THP-1 cells they were differentiated to macrophage-like cells by incubating them with TPA, before starting any assay. $3 \times 10^{5}$ cells/well were seeded in 96-well plate and were incubated for $24 \mathrm{~h},\left(37^{\circ} \mathrm{C}, 5 \% \mathrm{CO}_{2}\right)$. After $24 \mathrm{~h}$ of incubation, cells were induced with TPA $\left(10 \mathrm{ng} / \mathrm{ml}, 37^{\circ} \mathrm{C}\right.$, $5 \% \mathrm{CO}_{2}$ ) for $24 \mathrm{~h}$.

\section{MTT assay}

MTT assay was performed to estimate cell viability after each set of treatment. TPA induced cells (with/without treatment of BSC/Vasicine) in each well, were incubated with $10 \mu \mathrm{l}(5 \mathrm{mg} / \mathrm{ml}) \mathrm{MTT}$ for $3-4 \mathrm{~h}$ in a $\mathrm{CO}_{2}$ incubator. $100 \mu \mathrm{l}$ of DMSO was then added to dissolve the formazan formed and, the plate was incubated for another $10 \mathrm{~min}$ in dark at room temperature. Finally, the treatment plate was read in ELISA plate reader (bio red) using 570nm filter [16].

\section{Treatment with Bidi Smoke Concentrate (BSC)}

In order to evaluate the toxicity caused by $\mathrm{BSC}$, cells after TPA induction were treated with BSC (0-5\%) for 24 $\mathrm{h}$ and the cell viability was determined by MTT assay as described before. 


\section{Treatment with Vasicine}

To determine safe dose range of Vasicine, cells $(3 \mathrm{x}$ $10^{5}$ cells/well $)$ were treated with Vasicine $(0.25-6 \mu \mathrm{g} / \mathrm{ml})$ for $3 \mathrm{~h}$ and cell viability was determined by MTT assay as described before.

Pre-treatment with Vasicine and its effect on BSCinduced toxicity

To determine the cyto-protective ability of Vasicine, cells after TPA induction were pre-treated with $3 \mu \mathrm{g} / \mathrm{ml}$ Vasicine for $3 \mathrm{~h}$ (except control). This step was followed by addition of $3 \%$ BSC to each well (except control) and cells were further incubated for $24 \mathrm{~h}$. Cell viability was determined by MTT assay as described above.

\section{Microscopic analysis}

$1 \times 10^{4}$ cells were seeded in a 6-well plate over a glass cover slip and grown overnight in RPMI 1640 media (with 10\% FBS). After TPA induction, cells were treated with BSC, Vasicine and Vasicine + BSC as, mentioned above in MTT assay. After the treatment, the cells were washed with PBS (pH 7.4,20mM) and the cells on cover slip were observed under inverted microscope (Olympus, CH20i, USA) at 20X magnification [15].

\section{Superoxide dismutase (SOD) activity assay}

SOD activity assay was performed by Pyrogallol autoxidation method with certain modifications [17]. In this assay, cell lysate containing $50 \mu \mathrm{g}$ protein was added to $0.2 \mathrm{mM}$ pyrogallol (dissolved in $50 \mathrm{mM}$ PBS, $\mathrm{pH} 6.5$ ) to initiate the reaction, and decrease in absorbance was recorded at $420 \mathrm{~nm}$. The percentage inhibition of pyrogallol autoxidation was calculated by the following formula:

$\%$ inhibition of pyrogallol autoxidation $=\left[1-\left(\Delta \mathrm{A} / \Delta \mathrm{A}_{\max }\right)\right]$ $\mathrm{x} 100$

where,

$\Delta \mathrm{A}=$ Absorbance change due to pyrogallol autoxidation in the sample reaction system

$\Delta \mathrm{A}_{\max }=$ Absorbance change due to pyrogallol autoxidation in blank (without cell lysate)

One unit of SOD activity was defined as the amount of enzyme required to inhibit pyrogallol autoxidation by $50 \%$ per min.

\section{Measurement of NO production (Griess assay)}

The production of nitric oxide was estimated spectrophotometrically as, nitrite concentration formed, in cell-free culture supernatants, of different treated samples, as per standard protocol [18].

\section{Statistical test}

Statistical analysis for various assays was performed using the one way ANOVA test followed by Tukey test. P $<0.01$ was considered to be statistically significant as shown in the figure legends.

\section{RESULTS}

\section{Effect of Bidi Smoke Concentrate on the viability of} THP-1 cell Line

The cytotoxic effect of BSC in THP-1 cells was evaluated through MTT assay and it was found that, BSC showed dose dependent toxic effect at concentrations ranging from $0.5-5 \%$ (Figure 1). It is clear from this figure that, $\sim 50 \%$ reduction in cell viability was obtained with $3 \%$ BSC treatment, as compared to control.

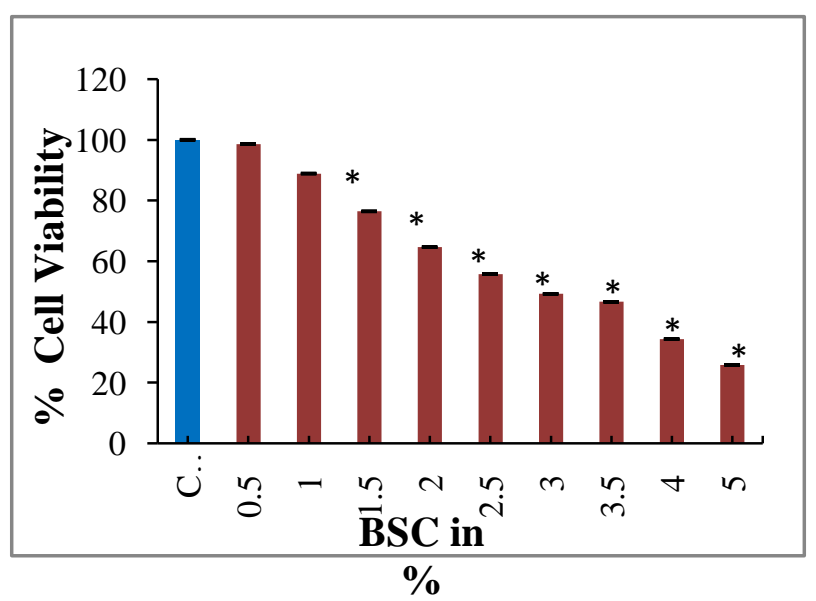

Figure 1: Effect of various concentrations of Bidi Smoke Concentrate (BSC) on cell viability of THP-1 cell line. The cell viability decreases to $\sim 50 \%$ at a concentration of $3 \%$ BSC. For statistical evaluations, one-way ANOVA analysis followed by Tukey test was used. $* \mathbf{P}<0.01$.

\section{Dose optimization for Vasicine}

Before analyzing protective effects of Vasicine, the cells were exposed to a range of concentrations of the Vasicine $(0.25-6 \mu \mathrm{g} / \mathrm{ml}$ for $3 \mathrm{~h})$, followed by MTT assay for dose optimization. The results showed that, Vasicine is safe within the concentration range of $1-3 \mu \mathrm{g} / \mathrm{ml}$ for THP-1 cells (Figure 2), and has shown a slight increase in cell viability (up to $104 \pm 2.9 \%$ ) at a dose of $3 \mu \mathrm{g} / \mathrm{ml}$. This 
dose was chosen for further evaluation of protective effect.

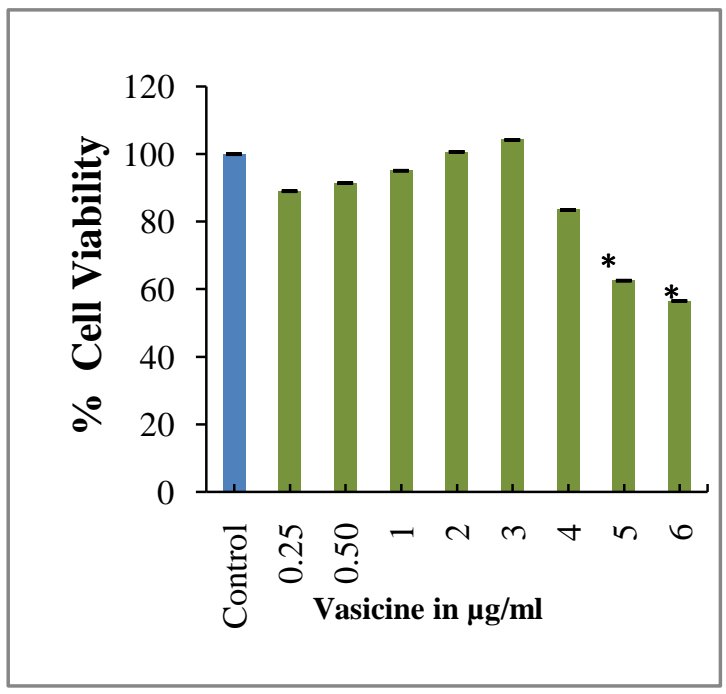

Figure 2: Effect of different concentrations of Vasicine $(0.25-6 \mu \mathrm{g} / \mathrm{ml}$ for $3 \mathrm{~h}$ ) on cell viability of THP-1 cell line. Vasicine was found to be safe from $1-3 \mu \mathrm{g} / \mathrm{ml}$. Cell viability was decreased once the Vasicine concentration exceeded $3 \mu \mathrm{g} / \mathrm{ml}$. For statistical evaluations, one-way ANOVA analysis followed by Tukey test was used. $* \mathbf{P}<0.01$.

\section{Preventive Effect of Vasicine in BSC-Induced Toxicity}

To evaluate the cyto-protective ability of Vasicine for BSC caused toxicity, cells were pre-treated with Vasicine $(3 \mu \mathrm{g} / \mathrm{ml}, 3 \mathrm{~h})$ before exposing it to BSC. It was observed that $3 \mu \mathrm{g} / \mathrm{ml}$ Vasicine pre-treatment cells could retained cell viability up to $11 \pm 0.03 \%$, more than BSC (only) treated cells. These results indicate that, pre-treatment with $3 \mu \mathrm{g} / \mathrm{ml}$ Vasicine is able to protect THP- 1 cells against BSC - induced toxicity (Figure 3) up to $\sim 89 \%$.

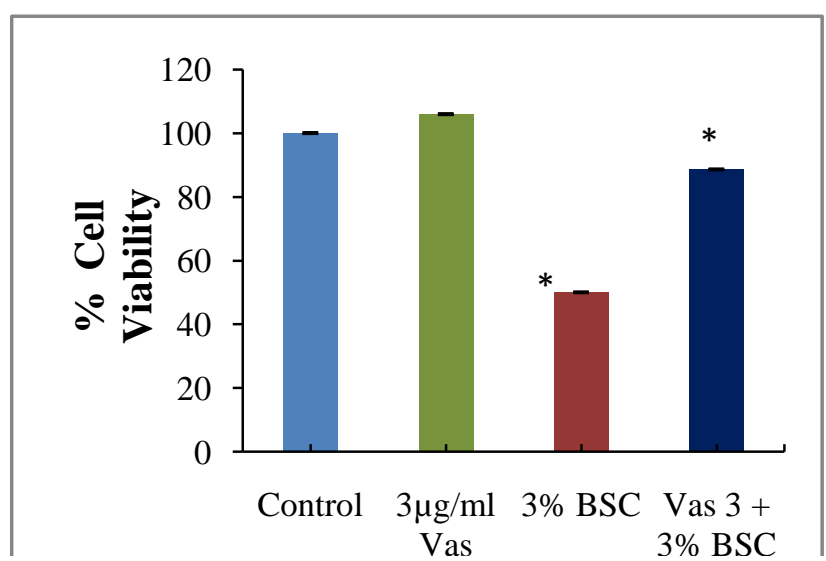

Figure 3: Effect of different treatments (Vasicine for $3 \mathrm{~h}, \mathrm{BSC}$ for 24 $h$, and their combinations) on cell viability in THP-1 cell line. Pretreatment of cells with $3 \mu \mathrm{g} / \mathrm{ml}$ Vasicine could retain cell viability up to $11 \pm 0.03 \%$, more than BSC (only) treated cells. For statistical evaluations, one-way ANOVA analysis followed by Tukey test was used. $* \mathbf{P}<0.01$.

\section{Microscopic analysis}

Microscopic analysis of cells treated with above sets (BSC, Vasicine and Vasicine + BSC) treatments showed that 3\% BSC exposure (Figure 4C) caused a tremendous decrease in cell density as compared to control (Figure 4A). Treatment of Vasicine alone did not shown any significant effect on number or morphology (Figure 4B). When cells were pre-treated with Vasicine before exposing to $3 \% \mathrm{BSC}$, number of viable cells was more in comparision to $3 \%$ BSC alone treated cells, (Figure 4D).

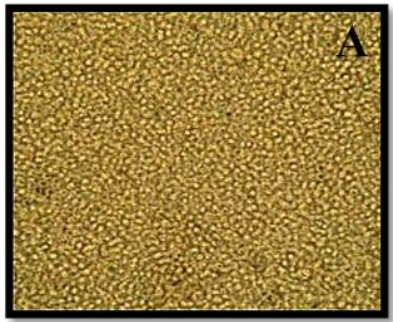

Control

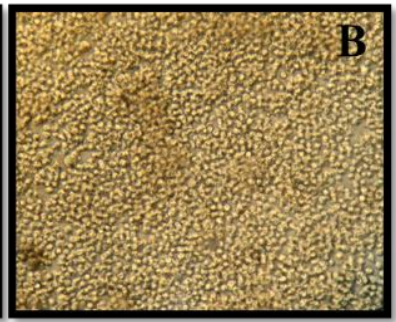

$3 \mu \mathrm{g} / \mathrm{ml}$ Vasicine

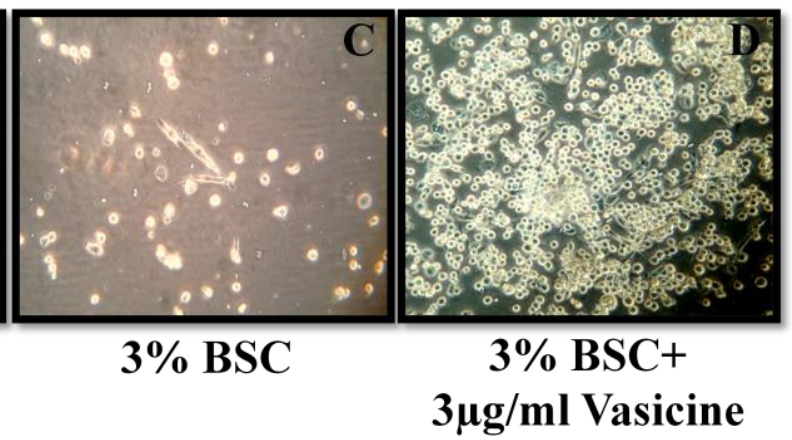

Figure 4: Microscopic analysis of THP-1 cells (A) control (untreated cells) (B) treated with $3 \mu \mathrm{g} / \mathrm{ml} \mathrm{Vasicine} \mathrm{(C)} 3 \%$ BSC treated and (D) $3 \%$ BSC treated cells which were pre-treated with $3 \mu \mathrm{g} / \mathrm{ml}$ Vasicine. Pre-treatment with Vasicine could retain more number of cells viable in comparison to the BSC exposed cells. 


\section{Measurement of NO level in THP-1 cell line}

Effect of various treatments on NO level was studied and, the results are shown in figure 5 . It is clear from the figure that $3 \%$ BSC has increased NO level (139\%) in macrophages compared to the control group. Vasicine treatment alone has shown decrease in NO level $(72 \%)$ but, pre-treatment with Vasicine (followed by 3\% BSC exposure) could maintain NO level up to $88 \%$ of the control.

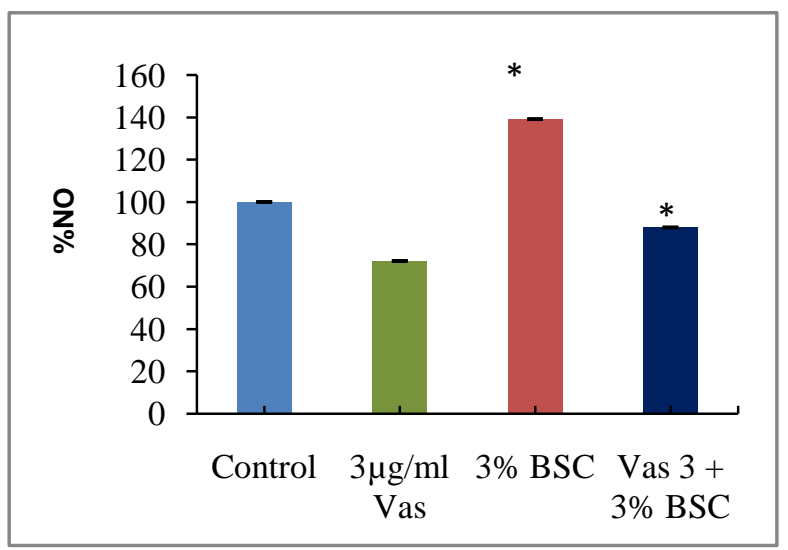

Figure 5: Effect of different treatments (Vasicine, BSC, and their combinations) on NO level in THP-1 cell line. Pretreatment with Vasicine (followed by BSC treatment) could maintain NO level up to $\mathbf{8 8 \%}$ in comparison to control. For statistical evaluations, one-way ANOVA analysis followed by Tukey test was used. * $\mathbf{P}<0.01$

\section{Superoxide Dismutase (SOD) enzyme activity}

Effects of various treatments on SOD enzyme activity were studied and the results have shown that $3 \% \mathrm{BSC}$ has increased SOD activity to $163 \%$ (Figure 6) in macrophages compared to the control group. Vasicine treatment alone has also shown to increased SOD activity (132\%). Pre-treatment with Vasicine (followed by $3 \%$ BSC exposure) seems to maintain SOD enzyme activity near to control $(108 \%)$.

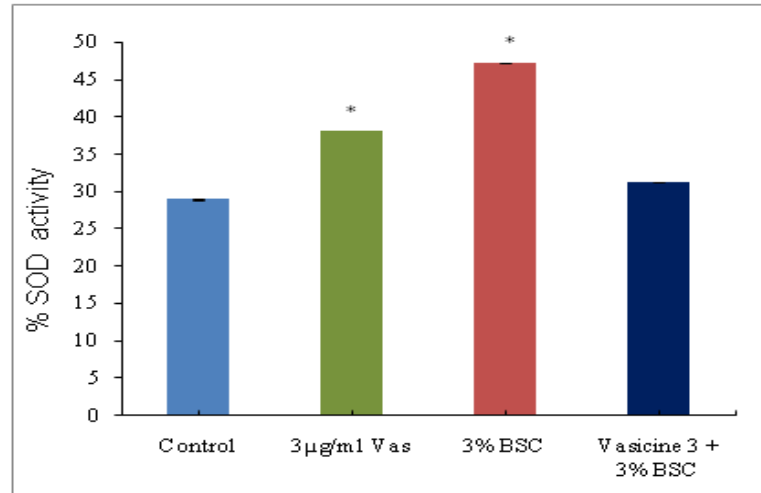

Figure 6: Effect of different treatments (Vasicine, BSC, and their combinations) on SOD enzyme activity in THP-1 cell line. Pretreatment with Vasicine (followed by BSC treatment) seems to maintain SOD activity near to control. For statistical evaluations, one-way ANOVA analysis followed by Tukey test was used. * $\mathbf{P}<$ 0.01.

\section{DISCUSSION}

Tobacco smoking has important relevance to the public health as, it has been found to be associated to many fatal diseases and disorders, including asthma, cardiac problems and cancer etc. It has been suggested that, tobacco smoke introduces and induces reactive oxygen and reactive nitrogen species (ROS \& RNS) production in the exposed biological system, affecting its oxidant state, which is responsible for altering the cell membrane integrity through lipid peroxidation [19] along with damaging various cellular proteins/enzymes, genetic material and other biological molecules. This affects the functionality/viability of the cells exposed to tobacco smoke [20]. As said above, ROS plays an important role in bringing about extensive damage to the biomolecules of the cells and tissues and, thereby lead to various diseased conditions, especially degenerative and inflammatory diseases due to extensive cell lysis [21]. These negative impacts are generally taken care of by the system itself by increasing production/activity of antioxidant enzymes and other molecules. These processes can further be triggered or aided by providing antioxidants from outside such as from the medicinal plants.

Similar to any other tissue/biological system, tobacco smoke has been reported to trigger oxidative stress and innate immune response in the respiratory system also, which further induces inflammatory responses, characterized by recruitment of neutrophils and macrophages in animal models and human smokers [2224]. These macrophages play a crucial role in mediating immune reactions against free radicals and bacterial, viral, and fungal infections as well as, in the pathophysiology of various other types of diseases like; chronic obstructive 


\section{Indo Global Journal of Pharmaceutical Sciences, 2015; 5(2): 99-105}

pulmonary disease (COPD) etc. [25, 26]. These events further increase oxidative stress and if, it becomes excessive, it can cause lung damage is a one of the major causes of many lung diseases. Hence, in this study, we analyzed the toxic effect of bidi smoke concentrate in THP-1 macrophage cell line, representing situation of alveolar macrophages in a smoker's lung.

There are numeral reports stating the importance of natural antioxidants isolated from different plant materials that could confer protection to cells against the detrimental effects of ROS [27-29]. Medicinal herbs contain several phytochemical compounds that are responsible for their antioxidant and other activities. Phenolics, alkaloids and flavonoids are the major constituents in most of the plants that are reported to possess antioxidant and free radical scavenging activity $[30,31]$. These compounds are known for their hydrogen or electron donating and metal ion chelating properties and, these findings have established an inverse relationship between the consumption of antioxidant rich plants and the incidence of human diseases [32].

For the present study, we had chosen Vasicine, an alkaloid and active compound of Adhatoda vasica, which is a very well known herb being used to treat respiratory diseases in Indian medicinal system. It is reported to be effective in respiratory ailments and other complications such as arthritis, diarrhoea \& dysentery, etc [12] but to the best of our knowledge, no work has been reported its role in tobacco smoke induced respiratory disorders so, the main objective of our study was to investigate if, Vasicine can protect THP-1 cells against BSC-induced oxidative stress and cytotoxicity. In this in vitro study, safe dose range for Vasicine was optimized to be 1$3 \mu \mathrm{g} / \mathrm{ml}$ by MTT assay as, it had shown no cytotoxic effect from on cells viability. While analyzing the toxic effects of BSC, it was observed that, 3\% BSC showed almost $50 \%$ cell cytotoxicity on human macrophages on exposing cells for $24 \mathrm{~h}$. These results were comparable with microscopic analysis.

Besides these, we also investigated if, Vasicine could improve antioxidant support system of the cells. While comparing the level of NO produced and SOD enzyme activity under various treatment conditions, it was found that $3 \%$ BSC could increase NO production and SOD level (39\% and 63\%, respectively) more than control. It can be suggested that in an attempt to overcome the toxic effects of BSC, the cells enhanced their SOD level/activity but, toxic NO production could not be controlled on their own. Whereas, when cells were pre treated with Vasicine it showed a decrease in NO level. SOD enzyme activity was also found to be maintained near to control by Vasicine pre treatment. It can be suggested that Vasicine being an antioxidant might have scavenged the ROS produced/present, by due to smoke exposure and increase in SOD activity must not be required to fight back the already nullified toxic situation. The other possibility could be the inherent increase in the level/activity of other antioxidants by Vasicine inside (less likely) the cells, and so increase in SOD activity was not needed for this reason. On the other hand Vasicine treatment could control NO production which a major initiator for oxidative stress and inflammatory cascade, and may avoid inflammatory conditions [33]. Further experimental proofs are required to establish these assumptions.

\section{CONCLUSION}

Present study suggests that bidi smoke concentrate can cause a considerable enhancement in the production of reactive oxygen species in human macrophage cell line and bring about considerable cell death. It seems from this study that cells try to combat the situation by increasing SOD activity. Vasicine pre-treatment has shown successful maintenance of the inherent antioxidant power of the cells in combating the BSC-induced oxidative stress as NO production was maintained by Vasicine, which is a good sign and indicates its mechanism of action by inhibiting NO mediated pathway. So, this study indicates that Vasicine could balance the oxidative state by controlling NO production inside the cells that can help the cells to survive against the deleterious effects of BSC induced oxidative stress.

\section{REFERENCES}

1. Pryor, W.A., Hales, B.J., Premovic, P.I., Church, D.F. The radicals in cigarette tar: their nature and suggested physiological implications. Science., 1983; 220: 425-427.

2. Alberg, A.J., Chen, J.C., Zhao, H., Hoffman, S.C., Comstock, G.W., Helzlsouer, K.J. Household exposure to passive cigarette smoking and serum micronutrient concentrations. Am J Clin Nutr., 2000; 72: 1576-1582.

3. Schumacher, J.N., Green, C.R., Best, F.W., Newell, M.P. Smoke composition. An extensive investigation of the water-soluble portion of cigarette smoke. J Agric Food Chem., 1977; 25: 310-320.

4. Cross, C.E., Traber, M., Eiserich, J., van der Vliet, A. A micronutrient antioxidants and smoking. Br Med Bull., 1999; 55: 691-704.

5. Panda, D., Miller, H.P., Wilson, L. Rapid tread milling of brain microtubules free of microtubule-associated proteins in vitro and its suppression by tau. Proc Natl Acad Sci., 1999; 96: 12459-12464.

6. Andrew, J.T., Teresa, D. Tetley Pulmonary epithelium, cigarette smoke, and chronic obstructive pulmonary disease. Int J Chron Obstruct Pulmon Dis. Dec., 2007; 2: 409-428.

7. Lohmann-Matthes, M.L., Steinmüller, C., Franke-Ullmann, G. Pulmonary macrophages Eur Respir J., 1994; 7: 16781689. 


\section{Indo Global Journal of Pharmaceutical Sciences, 2015; 5(2): 99-105}

8. Centers for Disease Control and Prevention (US), National Center for Chronic Disease Prevention and Health Promotion (US); Office on Smoking and Health (US). How Tobacco Smoke Causes Disease: The Biology and Behavioral Basis for Smoking-Attributable Disease: A Report of the Surgeon General. Atlanta (GA): Centers for Disease Control and Prevention (US); 2010.

9. Flora, S.J.S., Mittal, M., Mehta, A. Heavy metal induced oxidative stress \& its possible reversal by chelation therapy. Indian J Med Res., 2008; 128: 501-523.

10. Halliwell, B., Gutteridge, J.M.C. Free radicals, other reactive species and disease. In: Free radicals in biology and medicine Oxford: Oxford UP. 1998; 617-784.

11. Shrivastava, N., Srivastava, A., Banerjee, A., Nivsarkar, M. Anti-ulcer activity of Adhatoda vasica Nees. J Herb Pharmacother., 2006; 6: 43-49

12. Rachana, Basu, S., Pant, M., Priyanka, M.K., Saluja, S. Review \& future perspectives of using vasicine and related compounds. Indo-Global J Pharm Sci., 2011; 1: 85-98.

13. Srinivasarao, D., Indira, A., Jayarraj, R., Jayraaj, M., Lakshmi, P. A study on antioxidant and anti-inflammatory activity of vasicine against lung damage in rats. Indian $\mathrm{J}$. Allergy Asthma Immunol., 2006; 20: 1-7.

14. Shigeru, T., Michiko, Y., Yoshiko, Y., Yasuko, K., Tasuke, K., Keiya, Tada. Establishment and characterization of a human acute monocytic leukemia cell line (THP-1). Int $\mathbf{J}$ Cancer., 1980; 26: 171-176.

15. Pant, M., Basu, S., Rachana. Anti-oxidant activity and cytoprotective potential of ethanolic extract of Adhatoda vasica. Intern. J PharmTech Resarch., 2013; 5: 501- 510.

16. Hansen, M.B., Nielsen, S.E., Berg, K. Re-examination and further development of a precise and rapid dye method for measuring cell growth/cell kill. J. Immunol. Methods., 1989; 119: 203-210.

17. Marklund, S., Marklund, G. Involvement of the Superoxide Anion Radical in the Autoxidation of Pyrogallol and a Convenient Assay for Superoxide Dismutase. Eur J Biochem., 1974; 47: 469-474.

18. Green, L.C., Wagner, D.A., Glogowski, J., Skipper, P.L., Wishnok, J.S., Tannenbaum, S.R. Analysis of nitrate, nitrite, and $\left[{ }^{15} \mathrm{~N}\right]$ nitrate in biological fluids. Anal Biochem., 1982; 126: 131-138.

19. Hoshino, Y., Mio, T., Nagai, S., Miki, H., Ito, I., Izumi, T. Cytotoxic effects of cigarette smoke extract on an alveolar type II cell-derived cell line. Am J Physiol Lung Cell Mol Physiol., 2001; 281: 509-516.

20. Aprioku, J.S. Pharmacology of Free Radicals and the Impact of Reactive Oxygen Species on the Testis. J Reprod Infertil., 2013;14: 158-172.

21. Hazra, B., Biswas, S., Mandal, N. Antioxidant and free radical scavenging activity of Spondias pinnata. BMC Complement Altern Med., 2008; 8: 63.

22. Stämpfli, M., Anderson, G. How cigarette smoke skews immune responses to promote infection, lung disease and cancer. Nat Rev Immunol., 2009; 9: 377-384.

23. Tomita, $\mathrm{K}$. et al. Increased $\mathrm{p} 21(\mathrm{CIP} 1 / \mathrm{WAF} 1)$ and $\mathrm{B}$ cell lymphoma leukemia-x(L) expression and reduced apoptosis in alveolar macrophages from smokers. Am J Respir Crit Care Med., 2002; 166: 724-731.

24. Hansel, T.T., Barnes, P.J. New drugs for exacerbations of chronic obstructive pulmonary disease. Lancet., 2009; 374: 744-755.

25. Barnes, P.J. Alveolar macrophages as orchestrators of COPD. COPD., 2004; 1: 59-70.

26. Shapiro, S.D. The macrophage in chronic obstructive pulmonary disease. Am J Respir Crit Care Med., 1999; 160: 29-32.

27. Packer, L. Ong ASH: Biological oxidants and antioxidants: Molecular mechanisms and health effects. Champaign, IL: AOCS Press. 1997.

28. Jovanovic, S.V., Simic, M.G. Antioxidants in nutrition. Ann NY Acad Sci., 2000; 899: 326-334.

29. Dasgupta, N., Bratati, D. Antioxidant activity of some leafy vegetables of India: A comparative study. J Food chem., 2006; 10: 417-474.

30. Larson, C.P., Pless, I.B., Miettinen, O. Preschool behaviour disorders: their prevalence in relation to determinants. $\mathrm{J}$ Pediatr., 1988; 113: 278-285.

31. Williams, R.J., Spencer, J.P., Rice-Evans, C. Flavonoids: Antioxidants or signalling molecules? Free Rad Biol Med., 2004; 36: 838-849.

32. Rice-Evans, C.A., Bourdon, R. Free radical lipid interaction and their pathological consequences. Prog Lipid Res., 1993; 12: 1-110.

33. Wang, Y., Bai, C., Li, K., Adler, K.B., Wang, X. Role of airway epithelial cells in development of asthma and allergic rhinitis. Res Medicine., 2008; 102: 949-955.

Indo Global Journal of Pharmaceutical Sciences( ISSN 22491023 ; CODEN- IGJPAI; NLM ID: 101610675) indexed and abstracted in EMBASE(Elsevier), SCIRUS(Elsevier),CABI, CAB Abstracts, Chemical Abstract Services(CAS), American Chemical Society(ACS), Index Copernicus, EBSCO, DOAJ, Google Scholar and many more. For further details, visit 